\title{
PENDEKATAN SUPERVISI PENDIDIKAN
}

\author{
KURNIATI \\ Universitas Islam Negeri Alauddin Makassar \\ Email: kurniaamalia23@gmail.com
}

\begin{abstract}
:
Administration and supervision are supporting tools for achieving educational goal. Likewise also the purpose of school education can also be achieved if there is a systimatic and continous administration and super vision activities. Super vision theory from perspective of the approachused begins with directive supervision. But after seeing the axxistence of supervision ineffctiveness, the directive then emerged the teory of non directive supervision. But, after seeing the existence of supervision ineffectiveness, the directive then emerged the theory of non directive supervision. The ineffectiveness of directive supervision because directive supervision does not give teachers the opportunity to develop their abilities aand creativity, full responsibility is on the supervisor, so the supervisor is dominnt. This is one of the factors behind the birth of the ssupervisor directive.
\end{abstract}

Keyword: Appoarch, Education Supervision

\section{PENDAHULUAN}

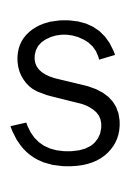

ecara etimologis supervisi berasal dari bahasa Inggris, to supervise, mengawasi' dalam Merriam Webster Colligate Dictionary disebutkan bahwa supervisi adalah a critical watching and directing. Sahertian (2000, h. 19) mendefinisikan supervisi sebagai suatu layanan kepada guru-guru. Istilah supervisi pada awalnya sangat populer dengan sebutan supervisi pendidikan yang dapat dijelaskan secara etimologi, morfologi maupuan semantik (Danim dan Khairil, 2011:152). Secara etimologi istilah supervisi dari bahasa Inggris supervision yang berarti pengawasan, secara morfologi supervisi terdiri dari dua kata yaitu super berarti atas dan visi berarti lihat, titik, dan awasi (Echols dan Shadily, 2009, h. 569). Seorang supervisor seharusnya memang mempunyai posisi di atas atau mempunyai kedudukan yang lebih tinggi dari orang yang disupervisi (Makawimbang, 2011, h. 71).

Administrasi dan supervisi merupakan alat penunjang untuk mencapai tujuan pendidikan. Demikian halnya juga tujuan pendidikan di sekolah dapat tercapai bila didalamnya ada kegiatan administrasi dan supervisi secara sistematis dan kontinyu. Kegiatan administrasi dan supervisi di sekolah dilaksanakan secara menyeluruh, meliputi hal hal yang berhubungan dengan kurikulum, murid, sarana dan prasarana dan hubungan sekolah dengan masyarakat (Burhanuddin, 2005, h. 98-99).

Proses interaksi dan hubungan antara pendidik dengan peserta didik adalah proses pendidikan. Untuk menjalin hubungan yang baik, maka pendidik perlu mengenal peserta didik dengan baik khususnya dalam kegiatan pembelajaran dalam suatu sistem dimana pendidik dan peserta didik aktif didalamnya. Kegiatan mengajar bagi para pendidik selalu mendapat tantangan maupun problem yang 
mengitarinya. Untuk mengatasi problem dan mengatasi berbagai tantangan dalam melaksanakan tugasnya sebagai pendidik, maka guru memerlukan bantuan dari seorang yang ahli di bidang pengajaran. Orang tersebut adalah seorang supervisor yang boleh saja orangnya adalah pengawas madrasah, kepala madrasah dan sejawat guru di madrasah yang mampu melaksanakan tugas sebagai supervisor. Seorang supervisor dapat menggunakan berbagai teknik supervisi akademik dalam upaya mengatasi problem dan tantangan yang dihadapi guru (Sagala, 2010, h. 210).

Usaha untuk meningkatkan mutu pendidikan tidak sedikit orang yang membicarakannya dan tidak sedikit pula jalan yang ditempuhnya, karena pendidikan memiliki peran strategis dalam mencetak generasi bangsa, dari pendidikanlah manusia mendapatkan berbagai macam ilmu yang menjadi bekal dalam hidupnya, dengan sekolah seseorang bisa mengenal angka, sejarah, perkembangan dunia dan yang utama dari itu semua, dengan pendidikan manusia bisa memahami hakikat dirinya sebagai hamba Allah swt. Menurut Suhertian, ada beberapa pendekatan yang dapat digunakan dalam supervisi yaitu pendekatan direktif, pendekatan non-direktif dan pendekatan kolaboratif, ketiga pendekatan tersebut bertitik tolak pada teori psikologi belajar (Muslim, 2010, h. 46-52).

Dalam dunia pendidikan kita mengenal keberadaan kepala sekolah, guru, dosen, siswa dan mahasiswa. Ke semua komponen ini memiliki peran masingmasing dan memiliki pengaruh berbeda-beda dalam mewujudkan keberhasilan pendidikan. Guru dan dosen berperan sebagai pentransfer ilmu dan pendidik bagi siswa dan mahasiswa. Sedang siswa dan mahasiswa sebagai objek didik. Untuk itulah guru diyakini sebagai kunci utama kesuksesan proses pendidikan dan pada akhirnya juga menjadi kunci utama kemajuan dan kemunduran.

Keberadaan guru sebagai pentransfer ilmu haruslah memiliki kreatifitas dalam menyampaikan ilmunya kepada siswa. Apalagi ilmu agama yang memiliki peran sangat urgen dalam menentukan keselamatan seseorang dunia akhirat, sehingga guru dituntut tidak hanya kreatif dalam metode penyampaian tetapi juga memiliki bekal ilmu psikologi. Oleh karena kesuksesan siswa memahami ilmu yang diberikan guru dipengaruhi oleh banyak faktor, selain aspek kognitif juga latar belakang keluarga termasuk minat siswa (psikologi siswa).

Tugas dan tanggung jawab guru yang tidak ringan ini, membutuhkan adanya orang-orang yang membantu menggali potensi yang dimiliki oleh guru. Orang-orang yang berfungsi sebagai motivator peningkatan kualitas guru ini disebut sebagai supervisor, sedangkan aktivitasnya disebut supervisi. Dalam satuan pendidikan, maka supervisor itu adalah kepala sekolah. Dari kegiatan supervisi inilah nanti diharapkan bisa meningkatkan kualitas guru dan mencari solusi atas masalah yang dihadapi guru.

Ada beberapa ragam supervisi yang beredar di dunia pendidikan saat ini. Diantaranya supervisi ilmiah, artistik, klinis, direktif, non direktif, kolaboratif dan lain sebagainya. Supervisi satu dengan lainnya diharapkan memudahkan supervisor 
dalam membina guru, karena ada banyak pilihan ragam supervise, dan teori-teori supervisi ini kebanyakan berkembang dengan dilandasi oleh teori psikologis. Adapun tokoh-tokoh yang mengembangkan teori psikologi ke dalam dunia supervisi diantaranya adalah Arthur Blumberg, Wiford A Weber, Lousi M dan lain-lain.

\section{HASIL PENELITIAN DAN PEMBAHASAN \\ Directive Approach}

Pendekatan direktif adalah cara pendekatan terhadap masalah yang bersifat langsung. Supervisor memberikan arahan langsung. Sudah tentu pengaruh perilaku supervisor lebih dominan. Pendekatan direktif ini berdasarkan pemahaman terhadap psikologi behaviorisme. Prinsip behaviorisme ialah bahwa segala perbuatan berasal dari refleks, yaitu respon terhadap rangsangan/stimulus. Oleh karena guru ini mengalami kekurangan, maka perlu diberikan rangsangan agar dapat bereaksi. Supervisor dapat menggunakan penguatan (reinforcement) atau hukuman (punishment). Pendekatan seperti ini dapat dilakukan dengan perilaku supervisor seperti: menjelaskan, menyajikan, mengarahkan, dan memberi contoh (Roestiyah, 2008, h. 20).

Pentingnya supervisi adalah untuk meningkatkan kemampuan profesional guru dalam meningkatkan proses hasil belajar melalui pemberian bantuan yang terutama bercorak layanan profesional kepada guru. Jika proses belajar meningkat, maka hasil belajar diharapkan juga meningkat. Dengan demikian, rangkaian usaha supervisi profesional guru akan memperlancar pencapaian tujuan kegiatan belajar mengajar. Secara umum supervisi memiliki kegunaan untuk memberikan bantuan dalam mengembangkan situasi belajar mengajar yang lebih baik, melalui usaha peningkatan profesional mengajar, menilai kemampuan guru sebagai pendidik dan pengajar dalam bidang masing-masing guna membantu mereka melakukan perbaikan dan bilamana diperlukan dengan menunjukkan kekurangan-kekurangan untuk diperbaiki sendiri (Sahertian, 2008, h. 19-21).

Supervisi berasal dari kata supervision yang terdiri dari dua kata yaitu super yang berarti lebih dan vision yang berarti melihat atau meninjau. Secara terminologi supervisi sering diartikan sebagai serangkaian usaha bantuan pada guru, sehingga supervisi secara etimologis mempunyai konsekuensi disamakannya pengertian supervisi dengan pengawasan dalam pengertian lama, berupa inspeksi sebagai kegiatan kontrol yang otoriter. Supervisi sebagai melihat atau meninjau dari atas atau menilik dan menilai dari atas yang dilakukan oleh pihak atasan (orang yang memiliki kelebihan) terhadap perwujudan kegiatan dan hasil kerja bawahan. Inspeksi diartikan sebagai kegiatan menyelidiki kesalahan para bawahan (guru) dalam melaksanakan instruksi atau perintah serta peraturan dari atasannya. Supervisi terutama sebagai bantuan yang berwujud layanan profesional yang dilakukan oleh kepala sekolah, penilik sekolah, dan pengawas serta supervisor lainnya untuk meningkatkan proses dan hasil belajar. Jika yang dimaksudkan 
supervisi adalah layanan profesional untuk meningkatkan proses dan hasil belajar, maka banyak pakar yang memberikan batasan supervisi sebagai bantuan kepada staf untuk mengembangkan situasi pembelajaran yang lebih baik (Sahertian, 2008, h, 16).

Adapun langkah-langkah pendekatan direktif yaitu menjelaskan, menyajikan, mengarahkan, memberi contoh, menetapkan tolok ukur, dan menguatkan. Dapat disimpulkan bahwa istilah prilaku supervisi yaitu: demonstrating (menunjukkan), directing (mengarahkan), standizing (mempersiapkan), dan reinforcing (memperkuat) (Muslim, 2010, h. 77).

Pendekatan ini lahir dari teori psikologi behaviorisme yaitu segala perbuatan berasal dari rileks, atau respons terhadap rangsangan/stimulus. Oleh karena itu guru yang mempunyai kekurangan perlu diberikan rangsangan agar guru bisa bereaksi dengan penguatan (reinforcement) atau hukuman (punishment). Adapun yang dimaksud dengan pendekatan direktif adalah cara pendekatan terhadap masalah yang bersifat langsung. Supervisor memberikan arahan langsung, dengan tujuan agar guru yang mengalami problem perlu diberi rangsangan langsung agar ia bisa bereaksi (Muslim, 2010, h. 46). Pendekatan ini lebih tepat digunakan terhadap guru yang acuh atau tidak bermutu (Muslim, 2010).

\section{Non Directive Approach}

Pendekatan supervisi non direktif adalah cara pendekatan terhadap masalah yang sifatnya tidak langsung. Pendekatan tidak langsung (non direktif) adalah cara pendekatan terhadap permasalahan yang sifatnya tidak langsung, sehingga perilaku supervisor tidak secara langsung menunjukkan permasalahan, tapi ia terlebih dulu mendengarkan secara aktif apa yang dikemukakan oleh guru.

Secara etimologi pendekatan memiliki arti usaha mendekati, sedangkan supervisi pendidikan secara terminologi didefinisikan sebagai serangkaian kegiatan untuk membantu personel sekolah dalam meningkatkan kemampuannya, sehingga lebih mampu mempertahankan dan melakukan perubahan penyelenggaraan sekolah dalam rangka meningkatkan pencapaian tujuan sekolah. Sedangkan kata non direktif bila diterjemahkan dalam bahasa Indonesia artinya tidak langsung.

Adapun secara teknis perilaku supervisor dalam pendekatan non direktif ini adalah: (1) Mendengarkan, dalam artian supervisor mendengarkan terlebih dahulu laporan-laporan guru baik berupa keberhasilan maupun permasalahan yang mereka hadapi. Seorang supervisor harus serius mendengarkan keluhan yang dihadapi guru hingga mengalami masalah yang sedang dia hadapi; (2) Memberi penguatan, setelah mengetahui berbagai keluhan yang dialami guru maka perilaku supervisor selanjutnya adalah memberi penguatan. Penguatan ini bisa berupa pujian, atau motivasi. Motivasi yang positif akan mendorong manusia untuk berbuat positif atau kebaikan juga. Sehingga dari penguatan yang berupa motivasi positif ini diharapkan mampu menghilangkan keburukan. Penjelasan supervisor kepada gurupun hendaknya disesuaikan dengan kapasitas kemampuan guru. Meskipun supervisi 
non direktif ini diberlakukan kepada guru yang professional, supervisor harus tetap memberikan penjelasan sesuai dengan tingkat pemahaman guru; (3) Menyajikan, bisa dimaknai dengan supervisor menyajikan solusi baik berupa petunjuk praktis atau teori. Dengan petunjuk praktis ini memudahkan guru untuk memahami ilmu yang diberikan oleh supervisor. Model penjelasan dengan petunjuk praktis ini bila kita merujuk pada metode pengajaran Rasulullah saw adalah nampak ketika Rasulullah mengajarkan sholat kepada kaumnya; (4) Memecahkan masalah, perilaku berikutnya adalah supervisor membantu memecahkan masalah yang dihadapi guru. Pemecahan masalah ini dalam rangka mengubah kondisi-kondisi yang tidak tepat menjadi tepat. Karena karakteristik supervisi non direktif ini bersifat dialog, maka dalam proses pemecahan masalah ini supervisor hendaknya dialog atau bermusyawarah dengan guru untuk mencari solusi bersama.

Mengacu pada definisi supervisi non direktif di atas, apabila kita kaitkan dengan konsep Islam, maka sesungguhnya Islam telah mewajibkan setiap individu untuk mengevaluasi proses pembentukan pribadi dan perbaikannya, dengan seluruh tindakannya. Islampun telah menetapkan bahwa dialah yang pertama harus bertanggung jawab terhadap dirinya sendiri. Adapun prinsip psikologi yang melandasi pendekatan supervisi non direktif adalah psikologis humanistik, dimana psikologi ini sangat menghargai orang yang akan dibantu. Oleh karena pribadi guru yang dibina begitu dihargai, maka supervisor lebih banyak mendengarkan permasalahan yang dihadapi guru. Oleh karena bersifat tidak langsung, maka supervisor tidak langsung menunjukkan permasalahan, tetapi memberikan ruang dan kesempatan yang luas bagi guru untuk menceritakan keberhasilan, keluhan dan masalah yang mereka alami. Baru kemudian memberikan stimulus untuk kebaikan ke depannya, sehingga guru menjadi subjek yang dominan.

\section{Collaborative Approach}

Pendekatan kolaboratif adalah cara pendekatan yang memadukan cara pendekatan direktif dan non direktif menjadi pendekatan baru. Pada pendekatan ini baik supervisor maupun guru bersama-sama, bersepakat untuk menetapkan struktur, proses dan kriteria dalam melaksanakan proses percakapan terhadap masalah yang dihadapi guru. Pendekatan ini didasarkan pada psikologi kognitif. Psikologi kognitif beranggapan bahwa belajar adalah hasil panduan antara kegiatan individu dengan lingkungan pada gilirannya nanti berpengaruh dalam pembentukan aktivitas individu. Dengan demikian pendekatan dalam supervisi berhubungan pada dua arah, yaitu dari atas ke bawah dan dari bawah ke atas. Perilaku supervisor adalah sebagai berikut: menyajikan, menjelaskan, mendengarkan, memecahkan masalah, dan negosiasi.

Pendekatan kolaboratif ini lahir dari psikologi kognitif yang beranggapan bahwa belajar adalah hasil paduan antara kegiatan individu dan lingkungan pada gilirannya nanti berpengaruh dalam pembentukan aktivitas individu. Dengan demikian pendekatan kolaboratif adalah cara pendekatan yang memadukan cara pendekatan 
direktif dan non-direktif. Pada pendekatan ini supervisor dan guru bersama-sama, bersepakat untuk menetapkan struktur, proses dan kriteria dalam melaksanakan proses percakapan terhadap masalah yang dihadapi, pendekatan kolaboratif ini mengunakan komunikasi dua arah, dari atas ke bawah dan dari bawah ke atas. Pendekatan ini di lebih tepat digunakan terhadap guru tukang kritik atau terlalu sibuk. Tugas supervisor adalah meminta penjelasan kepada guru apabila ada hal-hal yang diungkapkannya kurang dipahami, kemudian mendorong guru untuk mengaktualisasikannya inisiatif yang dipikirkannya untuk memecahkan masalah yang dihadapinya atau meningkatkan pengajarannya. Dengan demikian, dapat disimpulkan bahwa pada pendekatan kolaboratif ini, yang menjadi central adalah supervisor dan guru. Keduanya saling mengisi untuk menentukan perbaikan dan pengembangan kemampuan dan kreativitas guru.

Pendekatan kolaboratif ini diaplikasikan pada guru yang termasuk kategori guru energik dan guru konseptor dalam proses supervisi. Perubahan dan perbaikan merupakan dua frase yang menjadi core values bagi siapa saja yang ingin mendapatkan hasil terbaik (Ramli, 2005, h.1). Guru yang terlalu sibuk/energik, guru ini mempunyai tanggung jawab dan komitmen yang tinggi, tetapi tingkat abstraksinya rendah. Guru ini energik punya kemauan keras, dan antusias dalam bekerja. Citacitanya tinggi, ingin berprestasi melalui kerja keras dalam membina para siswa belajar bermaksud melakukan inovasi dalam pembelajaran agar lulusannya meningkat. Para siswa sering diberi tugas rumah yang banyak dengan harapan prestasi mereka meningkat. Tetapi kemauan besar dan niat baik itu terganjal oleh kemampuan umum guru ini yang kurang bagus, yang mengakibatkan jarang sekali guru dapat mewujudkan niat baiknya. Terlalu banyak yang ingin digapai tidak sesuai dengan kemampuannya yang rendah, membuat banyak pekerjaannya terbengkalai. Guru tukang kritik/konseptor, guru ini pandai membuat konsep-konsep baru tentang pembelajaran maupun sekolah, tetapi tidak mampu mewujudkan konsep itu. Hal ini disebabkan rasa tanggung jawab dan komitmennya rendah, walaupun guru memiliki tingkat abstraksi yang tinggi.

Dalam tugas sehari-hari guru sering mengemukakan ide-ide yang bagus yang sifatnya inovatif. guru dapat menjelaskan ide-ide itu dengan rasionalitas yang relative tepat beserta langkah-langkah mewujudkan program itu. Namun bila guru disuruh untuk mewujudkan cita-cita itu, memelopori hal-hal yang ia pandang inovatif, guru selalu menolak. Guru tidak mau berkorban waktu, tenaga maupun pikiran untuk merealisasi cita-cita itu. Guru tidak punya komitmen untuk melakukan sesuatu. Kolaborasi adalah kerja sama antara guru dan supervisor. pendekatan ini berasal dari psikologi kognitif. Kerja sama dilakukan dalam banyak hal untuk memajukan kedua guru ini. 


\section{PENUTUP/SIMPULAN}

Pendekatan supervisi non direktif adalah cara pendekatan terhadap masalah yang sifatnya tidak langsung. Sasaran supervisi non direktif adalah guru professional. Perbedaan pendekatan direktif dan non direktif meliputi enam hal. Pada pendekatan non direktif kegiatan dilakukan dengan kesadaran sendiri sedangkan pendekatan direktif tidak. Pada pendekatan non direktif keinginan dan tanggapan individu dihargai dan tidak disalahkan sedangkan pada pendekatan direktif tidak. Pendekatan non direktif diterapkan pada guru professional sedangkan pendekatan direktif pada guru tidak bermutu. Pada non direktif tidak diberlakukan pusnishment sedangkan pada direktif diberlakukan. Pada pendekatan non direktif guru yang dominan sedangkan pada pendekatan direktif supervisor yang dominan.

Metode mengajar non-directif (tidak langsung/tanpa menggurui) bisa digunakan untuk berbagai situasi masalah, baik masalah pribadi, sosial dan akademik. Dalam masalah pribadi, siswa menggali perasaannya tentang dirinya. Dalam masalah sosial, guru menggali perasaannya tentang hubungannya dengan orang lain dan menggali bagaimana perasaan tentang dirinya tersebut berpengaruh terhadap orang lain. Dalam masalah akademik, guru menggali perasaannya tentang kompetensi dan minatnya. Dari semua kasus di atas, esensi atau muatan wawancara harus bersifat personal, bukan eksternal. Artinya harus datang dari perasaan, pengalaman, pemahaman dan solusi yang dipilihnya sendiri.

Adapun secara teknis perilaku supervisor dalam pendekatan non direktif meliputi 5 hal yaitu: mendengarkan, memberi penguatan, menjelaskan, menyajikan dan memecahkan masalah. Tahapan dalam supervisi non direktif adalah percakapan awal (pre-conference), observasi, analisis/interpretasi, percakapan akhir (past conference), analisis akhir, diskusi. Penerimaan guru terhadap supervisi non direktif terdapat perbedaan, ada yang suka dan tidak suka. Namu dari hasil penelitian para pakar pendidikan diperoleh hasil bahwa guru professional menyukai supervisi non direktif.

Implementasi dari penelitian ini adalah cara yang perlu diperhatikan oleh kepala sekolah dalam melaksanakan tugas supervisi, yaitu: supervisi hendaknya dilaksanakan dengan persiapan dan perencanaan yang sistematis, serta supervisor hendaknya memberitahukan kepada orang-orang yang bersangkutan tentang rencana supervisinya.

Sebagai calon guru dan kepala sekolah harus mengetahui berbagai macam model pembelajaran tidak hanya model pembelajaran non-directif saja, ada banyak model pembelajaran yang bisa diterapkan dalam proses belajar-mengajar. Bagi kepala sekolah, pemberian pembinaan melalui supervisi pembelajaran terhadap para guru supaya terus menerus dilakukan, sehingga dapat terwujud lembaga pendidikan berkualitas. Kualitas pembelajaran merupakan kondisi yang mengarah pada keterlaksanaan pembelajaran yang ditujukan pada ketercapaian tujuan pendidikan. Ketercapaian tujuan pendidikan pada suatu lembaga sekolah hanya 
dapat dilakukan apabila kepala sekolah memiliki komitmen dan sikap dalam meningkatkan mutu pendidikan.

\section{DAFTAR PUSTAKA}

Burhanuddin, Yusak. 2005 Administrasi Pendidikan. Cet. III; Pustaka Setia: Bandung. Danim, Sudarwan dan Khairil. 2011. Profesi Kependidikan. Bandung: Alfabeta.

Echols, Jhon dan Hasan Shadily. 2009. An English-Indonesian Dictionary. Jakarta: Gramedia Pustaka Utama.

Makawimbang, Jerry H. 2011. Supervisi dan Meningkatkan Mutu Pendidikan. Bandung: Alfabeta.

Muslim, Sri Banun. 2010. Supervisi Pendidikan Meningkatkan Kualitas Profesionalisme Guru. Jakarta: CV Alfabeta, IKAPI.

Roestiyah. 2008. Strategi Belajar Mengajar. Jakarta: Rineka Cipta.

Ramli. 2015. Manajemen Pelayanan Publik Berbasis Kemanusiaan. Makassar: Alauddin University Prees.

Sagala, Syaiful. 2010. Kemampuan Profesional Guru dan Tantangan Tenaga Kependidikan. Bandung: Alfabeta.

Sahabuddin. 2007. Mengajar dan Belajar Dua Aspek dari Suatu Proses yang Disebut Pendidikan. Makassar: Badan Penerbit UNM.

Sahertian, Piet A. 2000. Konsep Dasar dan Teknik Supervisi Pendidikan Dalam Rangka Pengembangan Sumber Daya Manusia. Jakarta: Rineka Cipta. 